\title{
THE WELFARE OF ROMANIAN SOCIETY VIEWED FROM THE HISTORICAL AND SOCIO- ECONOMICAL PERSPECTIVE
}

\author{
Adina MIHĂILESCU ${ }^{1}$ \\ DOI: 10.35782/JCPP.2020.1.05
}

\begin{abstract}
Well-being is the satisfaction felt by each individual, in relation to what surrounds him, and which refers not only to the material conditions, namely the accumulation of goods and services, but also to safety of each, through which it can be put value on the individual personality. By comparing the budgets of different categories, we retrieve the way they operate after a certain hierarchy of needs, from the most elementary to the least needed. Studying the consumption model is necessary to see human needs at some point in a society. Consumer models make it possible to distribute economic resources optimally in order to improve the quality of life of individuals, groups, communities and the willingness to bring these levels of consumption closer. The structure of consumption is also linked to the level of preparation of the individual.
\end{abstract}

Keywords: wealth, population household, historical perspective, consumption patterns.

\section{Introduction}

Studying the consumption model is necessary to see human needs at some point in a society. Consumer models make it possible to distribute economic resources optimally in order to improve the quality of life of individuals, groups, communities and the willingness to bring these levels of consumption closer. The structure of consumption is also linked to the level of preparation of the individual. By comparing the budgets of different categories, we retrieve the way they operate after a certain hierarchy of needs, from the most elementary to the least needed. But at the same time, it is clear that other criteria work: rural or urban life, manual or intellectual work, employee or freelancer, etc. However, the structures of these budgets present significant differences. Not only because of the time evolution of life modes, but also because of the specific needs of different categories of population.

1 Senior Researcher, The Research Institute for Quality of Life, Romanian Academy, E-mail: adina.mihailescu@yahoo.com 
However, they began to manifest themselves in the genre of choosing a life as simple as possible without being affected by the fundamental needs, provided that this choice is the option of the individual and is voluntary. It seems that there are more and more followers of a low consumption of food, non-food and services, but without deprivation, and with obtaining satisfaction from other sources of life. There is a new culture linked to a simpler lifestyle, which respects the work itself with a low or modest income and appreciates a more moderate consumption than the ostentatial. This does not mean a life of sacrifices, but merely a simpler lifestyle. Those who opt for this lifestyle have been observed to enrich their existence with other kinds of concerns: study, public life, volunteering, participation in community activities, internet interaction, sport, cultural activities and nature observation or communion with it.

It can be appreciated that well-being is the satisfaction felt by each individual, in relation to what surrounds him, and which refers not only to the material conditions, namely the accumulation of goods and services, but also to a safety of each. That can be in connection with the personality of the individual.

\section{Period 1918-1948}

In thirty years of Romanian modern history, 1918-1948, it is imperative to ask ourselves: how have these people lived for three decades? What economic and social structure was existed in society? What were the occupations of the weather? How important was education or health? We receive the answers from the literary descriptions, specialized publications and official sources.

Romania, after the great Union, in the period 1918-1948, became a state of average size, occupying the eighth place in Europe as population and tenth place as territory. The census of 1930 presents the following structure of the Romanian population: $71.9 \%$ Romanians, 7.9\% Hungarians, 4.1\% Germans, 4\% Jews, 3.2\% Ruteni and Ukrainians, 2.3\% Russians, 2\% Bulgarians, 1.5\% Gypsy, 0.9\% Turks, 0.6\% Gagauz, 0.3\% Serbs and Croats, $0.3 \%$ poles, $0.1 \%$ Greeks, $0.1 \%$ Tatars, $0.3 \%$ other nationalities. Of the $18,025,896$ inhabitants, $78.9 \%$ lived in rural areas, and $21.1 \%$ were concentrated in urban. Romania's largest cities at the time were: Bucharest with 630,000 inhabitants, Cernăuti, Galați, Iaşi with 400,000 inhabitants (Population Census, 1940, p.133).

After the statistics of 1930s, the labour force distribution on professions was as follows:

- $72.3 \%$ worked in agriculture

$-9.4 \%$ in industry

$-4.8 \%$ were officials

- $4.2 \%$ were dealing with trade and credit.

The economic structure defines elements of the social structure as follows: in Transylvania the share of commercial and industrial bourgeoisie was small, then peasants and industrial workers; in Bucovina were predomination of capitalists of Jewish or German origin and peasants; in Basarabia the highest share have peasants. 


\section{Social structure in the interwar period}

The social structure in the interwar period knows some stages of evolution according to the development of economic branches. If in the period 1918-1921, the majority of the population was peasants, after 1922, the number of workers and liberal professions increases due to the development of the industry.

The industrial, banking and commercial bourgeoisie played an important role in economic and political terms. It boosted the most important act of economic policy, like the industrialisation in Romania, by increasing its economic power. The bourgeoisie strengthened its position in society and contributed to the modernisation of the Romanian state. Some measures of economic policy mitigated some social conflicts. The bourgeoisie was not a homogeneous social class, in our country, the small and middle bourgeoisie were prevailing. The great bourgeoisie was represented by the industrialists and bankers as Nicolae Malaxa, Max Auschnitt, Ion Gigurtu.

The great land owners were in a process of differentiation and disintegration. They lost economic and social-political influence in Romanian society. The process of political and economic disintegration begins in the early years of the twentieth century and accentuates itself at the end of World War I. They lose their importance after the Agrarian Reform of 1921.

The peasant was the majority of the population. It forms a social group composed of different categories delimited by the size of ownership, capital and the way of exploitation of the earth. The peasants know the stratification process formed by small agricultural owners and agricultural workers.

Industrial workers. The economic development of large Romania by diversifying industrial branches has led to the numerical increase of workers concentrated around industrial platforms in major cities. During the economic stability period, this class had an acceptable standard of living and becomes an important social-political force. By developing new industrial branches increases the degree of professional training of this class.

Intellectuality increases its number and role in society as a result of the development of education, science and culture. Romanian intellectuality was in progressive positions. It contributed to the development of higher and secondary education, came from both the world of villages and the cities area. This class knows a quantitative and qualitative increase. The most eloquent example is that the University of Bucharest was among the top 3 in the world. (http://www.rasfoiesc.com/educatie/istorie/structuri-si-miscarisociale-I92.php).

The liberal professions "were very high, but very few became good professionals, because the rigor was very strong, and they kind of dissipate after World War I, but the currency collapses. From that moment, political life becomes a profession, in the sense that it turns into a trophic chain of money-andtied business" (http://www.digi24.ro/stiri/actualitate/social/555-bucurestiul-meu-bucuresti-orasul-in-care-s-a-practicat-comertul-cu-afurisenii-309300). 
Data from 1930 Census show that the highest concentration of Romanian employees was in public administration $65 \%$, followed by agriculture with $45 \%$, transport and telecommunications $40.4 \%$, services, activities of public interest, liberal professions with $34.7 \%$.

If we analyze Hungarian employees (Table 1) they occupied the highest share in mining and extractive industry $68.2 \%$, followed by industry with $60 \%$, transport and telecommunications with $54.3 \%$ and in agriculture with more than half of the branch employees, $51.2 \%$. Commercial and Banking field were occupied the Jewish population with $36.6 \%$, followed by the industry by $15 \%$.

Table 1. Share of different ethnicities in certain occupations in the year 1930

\begin{tabular}{|l|c|c|c|c|c|c|c|c|c|c|}
\hline & \multicolumn{2}{|c|}{ Romanian } & \multicolumn{2}{c|}{ Hungarian } & \multicolumn{2}{c|}{ Jews } & \multicolumn{2}{c|}{ Others } & \multicolumn{2}{c|}{ Total } \\
\hline Agriculture & 2610 & $45.0 \%$ & 2971 & $51.2 \%$ & 127 & $2.2 \%$ & 95 & $1.6 \%$ & 5803 & $100 \%$ \\
\hline $\begin{array}{l}\text { Mining, } \\
\text { extractive } \\
\text { industry }\end{array}$ & 55 & $19.6 \%$ & 191 & $68.2 \%$ & 22 & $7.9 \%$ & 12 & $4.3 \%$ & 280 & $100 \%$ \\
\hline Industry & 6333 & $21.3 \%$ & 17847 & $60.0 \%$ & 4507 & $15.2 \%$ & 1062 & $3.6 \%$ & 29749 & $100 \%$ \\
\hline $\begin{array}{l}\text { Trade and } \\
\text { credit }\end{array}$ & 2380 & $18.4 \%$ & 5303 & $41.1 \%$ & 4728 & $36.6 \%$ & 502 & $3.9 \%$ & 12913 & $100 \%$ \\
\hline $\begin{array}{l}\text { Transport and } \\
\text { telecommuni- } \\
\text { cations }\end{array}$ & 4178 & $40.4 \%$ & 5614 & $54.3 \%$ & 279 & $2.7 \%$ & 261 & $2.5 \%$ & 10332 & $100 \%$ \\
\hline $\begin{array}{l}\text { Public } \\
\text { administration }\end{array}$ & 11099 & $65 \%$ & 3574 & $20.9 \%$ & 1055 & $6.2 \%$ & 1345 & $7.9 \%$ & 17073 & $100 \%$ \\
\hline $\begin{array}{l}\text { Services, } \\
\text { activities of } \\
\text { public interest, } \\
\text { liberal } \\
\text { professions }\end{array}$ & 7988 & $34.7 \%$ & 11452 & $49.8 \%$ & 1900 & $8.3 \%$ & 1675 & $7.3 \%$ & 23015 & $100 \%$ \\
\hline Unknown & 252 & $15.0 \%$ & 737 & $43.9 \%$ & 444 & $26.4 \%$ & 246 & $14.6 \%$ & 1679 & $100 \%$ \\
\hline Total & 34895 & $34.6 \%$ & 47689 & $47.3 \%$ & 13062 & $13.0 \%$ & 5198 & $5.1 \%$ & 100844 & $100 \%$ \\
\hline
\end{tabular}

Source: Population Census, 1940, p.133.

The Liberal services like medicine, law and engineering were dominated by Hungarians, Romanians and Jews.

\section{Economic structure of interwar Romania}

At the beginning of the analyzed period, leul (Romanian currency) was subjected to instability. Domestic prices have evolved under the strong influence of internal and external factors. The new influence factors came into action with the triggering of the First World War in 1914.

Here's how it is reflected in data the difficulties that were borne by the Romanian population compared to other developed, developing countries or countries that share the same political regime (Table 2). From the table, we see how our country at the level of the year 1938, that is, on the verge of World War II, ranked 20th as a gross national 
product per inhabitant, sixty years later, the same indicator placed Romania on the same spot, 20.

\section{Table 2. Ranking of European countries according to \\ Gross national product in the years 1938 and 1988, as well as the existing disparities}

\begin{tabular}{|c|c|c|c|c|}
\hline \multirow{2}{*}{ Country } & \multicolumn{2}{|c|}{$\begin{array}{c}\text { 1938 } \\
\text { (Romania } \mathbf{1 , 0 0 )}\end{array}$} & \multicolumn{2}{c|}{$\begin{array}{c}1988 \\
\text { (Romania = 1,00) }\end{array}$} \\
\cline { 2 - 5 } & Rang & Dissolutions & Rang & Dissolutions \\
\hline Great Britain* & 1 & 6.00 & 12 & 7.25 \\
\hline Sweden & $2-3$ & 5.82 & 3 & 10.85 \\
\hline Switzerland & $2-3$ & 5.82 & 1 & 15.44 \\
\hline Germany * & 4 & 5.36 & 5 & 10.50 \\
\hline Netherlands & 5 & 5.14 & 10 & 8.23 \\
\hline Denmark & 6 & 5.05 & 6 & 10.46 \\
\hline Belgium-Luxembourg & 7 & 4.52 & 9 & 8.24 \\
\hline Norway & 8 & 4.00 & 2 & 11.34 \\
\hline Ireland & 9 & 3.94 & 14 & 4.24 \\
\hline France & 10 & 3.76 & 7 & 9.11 \\
\hline Austria & $11-12$ & 2.87 & 8 & 8.81 \\
\hline Finland & $11-12$ & 2.87 & 4 & 10.54 \\
\hline Czechoslovakia & 13 & 2.76 & 15 & 2.24 \\
\hline Italy & 14 & 2.02 & 11 & 7.55 \\
\hline Hungary & 15 & 1.81 & 17 & 1.39 \\
\hline Poland & 16 & 1.65 & 19 & 1.05 \\
\hline Spain & 17 & 1.28 & 13 & 4.38 \\
\hline Bulgaria & 18 & 1.10 & 18 & 1.24 \\
\hline Yugoslavia & 19 & 1.08 & 16 & 1.52 \\
\hline Romania & $\mathbf{2 0}$ & $\mathbf{1 . 0 0}$ & $\mathbf{2 0}$ & $\mathbf{1 . 0 0}$ \\
\hline
\end{tabular}

* For year 1938, Great Britain. **For year 1988, exclusive GDR.

Source: For year 1938: Economic Survey of Europe in 1948, Genève 1949, p.235.

In the case of Romania, the data was calculated by specialists in the history of the national economy of the IEN.

Data from the year 1988, from the National Statistical Commission.

The existing disparities between Romania and the other countries of the world: advanced, developing or underdeveloped countries are measured by the following structure indicators (Table 3). The branch structure of GDP in advanced and developing capitalist countries has shown and evolved as evidenced by the following table. 
Table 3. Branch structure of GDP in advanced and developing capitalist countries

\begin{tabular}{|c|c|c|c|c|c|c|c|c|}
\hline $\begin{array}{c}\text { Group of } \\
\text { countries }\end{array}$ & $\begin{array}{c}\text { Perio } \\
\mathbf{d}\end{array}$ & $\begin{array}{c}\text { Agri- } \\
\text { culture }\end{array}$ & Industry & $\begin{array}{c}\text { Processing } \\
\text { industry }\end{array}$ & $\begin{array}{c}\text { Con- } \\
\text { struction }\end{array}$ & $\begin{array}{c}\text { Tran- } \\
\text { sport }\end{array}$ & $\begin{array}{c}\text { Trade } \\
\text { Other } \\
\text { branch } \\
\text { es }\end{array}$ \\
\hline \multirow{3}{*}{ Advanced } & 1950 & 7.9 & 32.6 & 28.0 & 5.8 & 6.7 & 14.7 & 31.4 \\
capitalistic & 1960 & 6.7 & 34.8 & 29.9 & 5.9 & 6.6 & 14.7 & 31.4 \\
countries & 1970 & 5.2 & 38.2 & 33.0 & 5.6 & 7.3 & 15.4 & 30.5 \\
& 2000 & 3.9 & 36.2 & 31.3 & 5.1 & 7.5 & 16.1 & 30.7 \\
\hline & 1950 & 36.6 & 16.2 & 13.7 & 3.5 & 5.1 & 12.9 & 21.6 \\
Non & 1960 & 33.9 & 20.5 & 17.1 & 3.9 & 5.2 & 14.1 & 21.0 \\
socialist & 1970 & 27.0 & 25.5 & 20.2 & 4.2 & 5.4 & 14.8 & 22.0 \\
developing & 1975 & 23.3 & 26.1 & 21.3 & 4.6 & 5.9 & 17.0 & 23.3 \\
countries & 2000 & 15.3 & 44.7 & - & - & 41.5 & - & - \\
\hline
\end{tabular}

Source: A.Vela, Dinamica structurii economice în țările în curs de dezvoltare, Bucuresti, Ed. stiintificăa si enciclopedică, 1981, p.257.

As the data shows, in 1950, in the second category countries, the share of agriculture was more than 4 times higher than those in the first category, which underlines the predominantly agrarian structure. The weak level of industrial development is marked by the weight gap of industrial production per total.

\section{Agriculture and rural population}

On the eve of the Second World War in the villages lived four-fifths of the population, of which a million peasant families had no land (Păun, 1994, p. 64). Worrying for Romanian agriculture is that the overwhelming part of the arable surface is in tiny, subsistence households with uncertain economic and productive future. Romania has a much more crummy rural property than near World War II. The Agrarian Reform of 1945 stressed the preponderance of peasant household in Romanian agriculture. After the reform, the land property was assigned as shown in the following table:

Table 4. Land property structure after the agrarian reform of 1945

\begin{tabular}{|c|c|c|}
\hline Types of property (ha) & Holdings (\%) & Agricultural area held (\%) \\
\hline Under 1 ha & 36.4 & 6.6 \\
\hline $1-3$ & 42.1 & 27.3 \\
\hline $3-5$ & 12.7 & 17.0 \\
\hline $5-10$ & 6.6 & 34.4 \\
\hline $10-20$ & 1.5 & 7.5 \\
\hline $20-50$ & 0.4 & 5.0 \\
\hline Over 50 ha & 0.3 & 2.2 \\
\hline
\end{tabular}

Source: Păun, Ion Otiman, Agricultura României la cumpăna dintre milenïle II şi III, Timişoara, Ed. Helicon, 1994, p.64. 
More than $97 \%$ of holdings had up to 10 hectares and owned $85.3 \%$ of the agricultural area. Triggered in the summer of 1949 the collectivization process has progressed slowly due to the resistance of the peasant (table 5):

Table 5. Number of GAC units and families during collectivization period 1949

\begin{tabular}{|c|c|c|c|}
\hline Year & $\begin{array}{c}\text { Number of units } \\
\text { (G.A.C.) }\end{array}$ & $\begin{array}{c}\text { Number of families in } \\
\text { G.A.C. (Thousand) }\end{array}$ & $\begin{array}{c}\text { Agricultural area } \\
\text { (Thousand ha) }\end{array}$ \\
\hline 1949 & 56 & 4.0 & 14.3 \\
\hline 1952 & 1795 & 165.5 & 713.4 \\
\hline 1955 & 2152 & 183.2 & 905.8 \\
\hline 1958 & 3028 & 468.5 & $1,892.5$ \\
\hline 1961 & 6424 & 2,051 & $5,937.3$ \\
\hline 1962 April & 6546 & 3,194 & $8,862.0$ \\
\hline
\end{tabular}

Sursa: Agricultura României 1944-1964, București, Ed. Agro-silvică, 1964, p.49.

\section{Cost of life}

During the First World War (1918) the cost of life was calculated for the basic products consumed by a family of five persons, the head of the family being a middle employed (Comunicări ştiințifice, 1945, 1948).

The following were included in the consumer basket:

1. Food: bread, cornmeal, sugar, flour, cow meat, pork, fats, milk, cheese, eggs, birds, fish, pasta, fruit vegetables.

2. Clothing and footwear: zefir, chiffon, thread, men's tights, women's stockings, fabric, men's shoes, women's shoes, soles, garments for ladies.

3. Fuel: Firewood, oak and beech, mangal, petroleum, gasoline alcohol.

4. Transport: Tickets and tram subscriptions.

5. Rent, water, light: The rent for an apartment, water, light.

6. Medications and miscellaneous: Refined alcohol, aspirin, quinine, iodine tincture, cotton wool, laundry soap, toilet soap, laundry soda, toothpaste.

The prices based on which the calculations were made are both real and legal prices. Between actual and legal prices, an average was carried out in the calculation of which the quantities were appreciated at legal prices. The amount of expenditure on the basis of which the index was calculated was determined by multiplying the above prices with the quantities of products and the share of services, allegedly consumed on average by a family of medium-sized officials composed of five members. Since the end of 1939, in determining the amount of expenditure, account has been taken of the movement produced in the structure of consumption with the disappearance of some of the products or decreasing the number of others. The indices thus calculated measure the evolution of the main maintenance costs. 
On the eve of the Second World War in the villages lived four-fifths of the population, of which 1 million peasant families had no Land (Romanian Encyclopedia vol. III). Worrying for Romanian agriculture is that the overwhelming part of the arable surface is in tiny subsistence households with uncertain economic and productive future.

Virgil Madgearu characterize the peasant household "The peasant family if they cannot resort to the work of annexes is forced to consumed from the substance of the holding, selling part of the inventory or calling for loans. Agricultural holdings of less than 3 hectares although they give the largest agricultural income per ha have the lowest income per person, which requires family members to seek to exploit their arms outside the household in order to ensure their maintenance in this way. Although in the operating group 3-5 ha the ratio between income and consumption is more satisfactory, the family's life needs still outnumber the income" (Enciclopedia Românească, 1940, p. 39).

The standard of living of the population in the Romanian Encyclopedia was mentioned as "The rural population and that of the outskirts of the cities are in a highly precarious material state. Mortality is very high. Social diseases have taken a worrying stretch. The number of illiterate is no longer compatible with the current situation of Romania (...)" (Encyclopedia of Romania, 1940, p. 223); "and now a few figures on the food of our population in 1937: annual meat consumption per inhabitant 3.4 kilograms, and wheat 323 grams (in Bulgaria 582) per day. In turn, the average annual consumption of sugar per inhabitant was 5.8 kilograms" (Encyclopedia of Romania, 1940, p.224).

With regard to housing "of 3,078,820 rural dwellings, one million are land houses, and 100,000 buts (i.e. buried in the ground). Of the three million dwellings, 600,000 have simple pieces of glass in the walls, and 800,000 are covered with cane or straw and, finally, two million have no floor" (Encyclopedia of Romania, 1940, p. 224).

\section{Table 6. Consumption baskets per inhabitant during the period 1938-1989 (60 years)}

\begin{tabular}{|l|c|c|c|c|c|c|c|}
\hline \multicolumn{1}{|c|}{ Product } & $\mathbf{1 9 3 8}$ & $\mathbf{1 9 5 0}$ & $\mathbf{1 9 6 0}$ & $\mathbf{1 9 7 0}$ & $\mathbf{1 9 8 0}$ & $\mathbf{1 9 8 5}$ & $\mathbf{1 9 8 9}$ \\
\hline Meat and meat products (kg) & 21.1 & 16.7 & 267 & 31.2 & 62.0 & 55.1 & 50.2 \\
\hline Milk and milk products (1) & 109.0 & 107.6 & 123.0 & 110.7 & 162.9 & 170.6 & 135.9 \\
\hline Eggs (pieces) & 73 & 59 & 109.0 & 142.0 & 232.0 & 254.0 & 229.0 \\
\hline Sugar and sugar products (kg) & 5.3 & 6.9 & 11.0 & 19.3 & 28.2 & 26.3 & 24.7 \\
\hline Potatoes (kg) & 40.0 & 50.3 & 83.5 & 62.3 & 70.6 & 78.4 & 71.7 \\
\hline $\begin{array}{l}\text { Vegetables and vegetable } \\
\text { products (kg) }\end{array}$ & 44.0 & 65.6 & 91.0 & 86.7 & 121.4 & 169.8 & 135.6 \\
\hline Fruit and Fruit products (kg) & 40.0 & 20.7 & 30.3 & 34.6 & 45,8 & 71.0 & 53.9 \\
\hline $\begin{array}{l}\text { Fabrics (inclusive confections) } \\
\text { (Square meters) }\end{array}$ & - & 13.19 & 15.83 & 19.34 & 28.59 & 28.14 & 27.88 \\
\hline Footwear (pair) & - & 0.62 & 1.49 & 2.62 & 3.50 & 3.75 & 3.62 \\
\hline
\end{tabular}

Source: Anuarul Statistic al României 1990, Tab. 56 - Consumul mediu anual pe locuitor la principalele produse alimentare si nealimentare, pg. 129.

Subsequently (Table 6) the consumer basket of the Romanian population, from 1938 until the Revolution of 1989, evolved as follows: the consumption of meat per capita was $21 \mathrm{~kg}$ and then increased significantly in 1980 to $62 \mathrm{~kg}$, it seems a peak year of the Romanian 
economy, after which this consumption decreases to $50 \mathrm{~kg}$ per month for a resident in 1989. Egg consumption knows a spectacular evolution from 73 buckers per month/person in 1938 , to 229 pieces in 1989. Sugar increased from $5 \mathrm{~kg} / \mathrm{month} /$ person in 1938 to almost 25 $\mathrm{kg} / \mathrm{month} /$ person in 1989, potatoes another basic food has experienced an increase from 40 to $70 \mathrm{~kg} / \mathrm{month} /$ person, the consumption of vegetables increased in 60 years 3 times, and the fruit once and a half (from 40 to $54 \mathrm{~kg} / \mathrm{month} /$ person).

At the beginning of the analysis period, the main cause that affected the health of the peasants was defective nutrition. The main food consumed by the Romanian peasants was corn, especially in Muntenia, Oltenia and Moldova. It had reached a quantity of three kilos daily by an adult person. In the west of the country, in southern Basarabia and in Dobrogea, bread made on the oven or fireplace, wheat and barley were used, which, however, was consumed in smaller quantities than corn. However, excessive carbohydrate consumption is found to the detriment of animal proteins and lipids. Milk and dairy products were consumed especially in the pastoral areas of Bucovina, Transilvania and southern Basarabia, but in other parts of the country, milk consumption was very low. $48 \%$ of peasant households didn't even have a cow.

Also, a large number of peasant families did not consume eggs because they kept them for sale in the city. In some villages in Moldova, the consumption of eggs was 40-70 eggs per year by person. As a rule, the peasants sold eggs and chickens to the city to procure the money needed for a lot of expenses. For this reason, the consumption of beef and chicken was at a very low level. "After some calculations, the Romanian peasants ate up to 20 kilograms of meat annually, which was consumed especially in winter. To these quantities must be added to the fish which, in areas with flowing waters or ponds, was frequently consumed. However, there were differences in the consumption of meat from one region to another. For example, in the west of the country was the favorite pig, and even an appreciable amount of bacon, including during the summer. In the eastern part of the country, this consumption was lower than the overall average per country" (http:/ / adevarul.ro/locale/targu-jiu/sanatatea-extrem-proasta-romanilor-perioada-interbelica-trei-milioane-copii-morti-intr-o-perioada-22-ani1_57d96d095ab6550cb8a8acbe/index.html).

The standard of life of the individual has the greatest influence, over $50 \%$ on his health, then inherited genetic material, the adopted lifestyle and environmental factors (eating habits, physical exercise, stress, working conditions, prevention and treatment behavior health problems, tobacco consumption, alcohol etc.), the level of education of the individual. (Doboş, 2005, p.3)

\section{Health}

In the interwar period, the health of Romanian peasants was quite shaky. Romania had a high mortality, both in the urban environment, but especially in rural areas. Sorin Buzatu, a history professor, conducted a research on peasants' health and concluded that high mortality was the consequence of overpopulation of housing: "Overcrowded, poorly ventilated and poorly lit houses favored the transmission of diseases. Debility of the organisms shows a higher number of dead persons, sometimes double compared to those neater houses and in which fewer people lived" (http://adevarul.ro/locale/targu-jiu/sanatatea-extrem-proasta-roma- 
nilor-perioada-interbelica-trei-milioane-copii-morti-intr-o-perioada-22-ani1_57d96d095ab6550cb8a8acbe/index.html).

According to the study, the highest mortality was encountered in Moldova, where 22.7 people died to 1,000 inhabitants. The few died in Bucovina, 18.2 at 1,000 inhabitants. The same study shows that mortality was very high among children. Approximately $40 \%$ of the total number of deaths came from among children, and in the 22 years of the interwar period, three million children died.

In the '30s, Romania was part of the first three countries in Europe with the highest infant mortality. Approximately $40 \%$ of the deaths of one year were children under 5 years of age. A large number of children died especially in the summer due to digestive conditions, due to the negligence of mothers caught by household chores, which did not ensure proper hygiene and were not attentive to the food they consumed (breastfeeding) and the little ones. A large number of deaths (13.1\%) it was caused by diseases of the respiratory apparatus and broncho-pneumonias, especially during the winter period.

In the states of Northern and Western Europe, such as Belgium, Denmark and Germany, life expectancy was about 70-75 years, compared to the one in Romania which was for 40 years. In the year 1930, Doctor George Banu conducted thorough research on a number of 2,149 children of school age, from urban and rural areas. The children from rural areas had not a normal weight in a proportion of $36.9 \%$. "It also drew attention to an extremely painful fact, not less than $67.5 \%$ of the children searched from the rural areas had at least one of deceased brothers, while the equivalent of the city was somewhat smaller, namely, 53.8\%" (http://adevarul.ro/locale/targu-jiu/sanatatea-extrem-proasta-romanilorperioada-interbelica-trei-milioane-copii-morti-intr-o-perioada-22-ani-

1_57d96d095ab6550cb8a8acbe/index.html).

\section{Period 1948-1989}

In the timeframe 1948-1989 an accelerated industrialization was performed. Electrification was realized. In agriculture, the property had the following distribution: $15.6 \%$ returned to private producers (in hill and mountain areas), 54.7\% to cooperative units and $29.7 \%$ of state units. Average size of a cooperative area was 2,500 ha.

From table 7 we notice how in 20 years, 1980-1989:

- the share of food and service costs has increased but not significantly to the families of employees, but has decreased the share of expenditure on non-food products

- in peasant families, food consumption has increased more than in employees, but the non-food and service expenses have decreased. 
Table 7. The structure of total consumption expenditures of cooperative households and peasants from 4 persons in the period 1980-1989 (20 years)

\begin{tabular}{|l|c|c|c|c|c|c|c|}
\hline $\begin{array}{c}\text { Total consumption } \\
\text { expenditures in employees' } \\
\text { families }\end{array}$ & $\mathbf{1 9 8 0}$ & $\mathbf{1 9 8 5}$ & $\mathbf{1 9 8 9}$ & $\begin{array}{c}\text { Total consumption } \\
\text { expenditures in cooperative } \\
\text { peasants' families }\end{array}$ & $\mathbf{1 9 8 0}$ & $\mathbf{1 9 8 5}$ & $\mathbf{1 9 8 9}$ \\
\hline \multicolumn{1}{|c|}{ Total } & 100.0 & 100.0 & 100.0 & Total & 100,0 & 100.0 & 100.0 \\
\hline $\begin{array}{l}\text { Food (including own } \\
\text { resources) }\end{array}$ & 44.7 & 48.8 & 49.7 & $\begin{array}{l}\text { Food (including own } \\
\text { resources) }\end{array}$ & 59.2 & 63.2 & 65.9 \\
\hline Non-food products & 38.9 & 35.0 & 33.0 & Non-food products & 32.3 & 29.2 & 27.1 \\
\hline Services & 16.4 & 16.2 & 17.3 & Services & 8.5 & 7.6 & 7.0 \\
\hline
\end{tabular}

Source: INS, Anuarul Statistic al României 1990, Tab. 61 - Structura cheltuielilor totale de consum ale familiilor de salariaţi și de țărani cooperatori cercetate pe eşantionul bugetelor de familie pe grupe după mărimea familiei, pg.129, 1991.

\section{0s and so far}

On January 1, 1990 Romania was the only country that had no external debts and held an available of nearly $\$ 2$ billion, after the data published by the World Bank. The country's population decreases, the main cause was poverty. The estimates of the Ministry of Labour and Social provisions, in the year 1994, showed that unemployed people under the age of 25 represent 38.3\%, those between 25-29 years 15.8\%, and those between $30-39$ years $22.9 \%$. So, the majority of $77 \%$ of unemployed people are young and very young (under 40 years).

In the years of the transition to market economy, Romania was once again the most heavily tested country in the group of Central and Eastern European countries, with the lowest minimum wage on economy in Europe, the lowest allocations from GDP for social protection in Europe, the most The disastrous system of medical services, the most disadvantageous system of privatization of means of production, the most radical dislocation of the indigenous industry with dramatic effects in the field of jobs and regional development and the economy in ensemble (Stanciu Mariana (coord.), 2012).

Romanians have evolved over the last twenty-seven years towards a special psychological profile in which have had combined cares and confidence. Has increased the number of those who have lost confidence in the capacity of Romanian Society (table 9), in the country's governments to solve problems (Bădescu, 2013).

We can consider the welfare state as a social institution that produces, organizes, distributes and regulates social goods and services and is responsible for providing people with both agreed goods and services to protect families and individuals against social contingencies and for to stabilize the socio-economic environment. This responsibility can be based on the notion of citizenship or, more broadly, on ethical grounds, the state must provide at least a certain basic level of protection for all its citizens (Cace, 2014, p.39). 
Table 9. Perception of income and needs ratio in 1994

\begin{tabular}{|l|c|c|}
\hline Revenue scale & Peasants & $\begin{array}{c}\text { The rest of the } \\
\text { sample }\end{array}$ \\
\hline Revenues do not reach us for the strict necessary & 34.4 & 28.7 \\
\hline I only arrive for the strict necessary & 47.2 & 40.0 \\
\hline Arrive for a decent living but no more & 12.8 & 22.1 \\
\hline With efforts we exceed the decent level & 5.6 & 8.0 \\
\hline We have everything necessary without great effort & - & 1.2 \\
\hline
\end{tabular}

Source: Zamfir Cătălin (coord.), Dimensiuni ale sărăciei, 1994, p.56.

The analysis of the caloric intake of different food groups highlights the fact that, on the whole of households, cereals and cereal products (table 10) provide almost half the number of calories (40.9\%) (INS, 2016, 2017, p. 225).

On the whole of households, meats and meat preparations held a modest share in the number of calorie-eating content, $(2.9 \%)$. Calories from milk, dairy products (cheeses and sour cream) and eggs have a share of $3.3 \%$ in the total number of calorie in household consumption. Instead, vegetables, potatoes, beans and other legumes only hold $15.3 \%$ of the total calories on the whole household.

Table 10. Caloric intake of main foodstuffs in the year 2015

\begin{tabular}{|l|c|}
\multicolumn{2}{l}{} \\
\hline Cereals and cereal products & -total households- \\
\hline Meat and meat preparations & $2.5 \%$ \\
\hline Milk, dairy products and eggs & $2.9 \%$ \\
\hline Fats, total & $3.3 \%$ \\
\hline Vegetables, canned vegetables, potatoes and bean beans & $7.9 \%$ \\
\hline Fruits and melons & $15.3 \%$ \\
\hline Sugar, sweeteners, chocolate and other sugary products & $11.0 \%$ \\
\hline Other products & $12.2 \%$ \\
\hline
\end{tabular}

Source: INS, Anuarul Statistic 2015, Bucuresti, 2016.

Bread and franzelery products are one of the basic foods for all categories of households analysed (Iagăr E.M. et al., 2016). On the whole of households, in the year 2015, average monthly consumption was $8.38 \mathrm{~kg} /$ person, meaning annually $100.6 \mathrm{~kg} /$ person. The lowest consumption of bread and franzelery products was registered with households $(8.11 \mathrm{~kg} /$ person).

Significant differences between the level of consumption of bread and franzelery products are found in households grouped by deciles. The lowest consumption was recorded in decile D10 $(6.81 \mathrm{~kg} /$ person) and the highest in decile D3 (8.74 kg/person). It is observed how from a certain level the consumption of cereal products decreases, being substituted with other foods with higher nutritional value.

The consumption of meat and meat preparations is of relatively low level compared to standards in developed countries. The average monthly consumption of fresh meat per 
person was, in the year 2015, of $3.39 \mathrm{~kg} /$ person. Households consisting of one person have the richest meat consumption $(4.73 \mathrm{~kg} /$ person monthly fresh meat).

Milk consumption was, in the year 2015, on average monthly, of 5.76 liters/person. In the year 2015, the highest level was recorded in pensioners (6.26 litres/person in 2015), and the lowest in the unemployed (4.77 litres/person in 2015). The highest consumption of milk is recorded in households consisting of one person (7.57 liters/person per month), the explanation would be that in most cases, older people predomination.

The consumption of cheeses and sour cream has similar characteristics to that of milk. It is higher in pensioners (1.39 kg/person) and lower in unemployers (0.96 kg/person). The level of the consumption of cheeses and sour cream is recorded in households consisting of one person $(1.86 \mathrm{~kg} /$ person).

Potatoes is a food that is consumed in relatively close quantities in all categories of households. On the whole of households, in the year 2015, average monthly consumption per person was $3.20 \mathrm{~kg}$. A single-person household had consumed 4.73 $\mathrm{kg} /$ person monthly, compared with $2.80 \mathrm{~kg} /$ person monthly in households consisting of 6 and more people.

The consumption of vegetables and canned vegetables was, in the year 2015, of $7.55 \mathrm{~kg}$, on average monthly per person. The highest consumption was recorded in single-person households (11.46 kg/person) and in households without children $(8.40 \mathrm{~kg} / \mathrm{person})$ and the smallest in households with 4 and more children (4.59 kg/person) and respectively in those consisting of 6 and more people $(5.43 \mathrm{~kg} /$ person).

The consumption of fruit is of relatively low level, on the whole of households, the average monthly consumption per person being $3.69 \mathrm{~kg}$ in year 2015. More important differences $(2.96 \mathrm{~kg} /$ person) are reported between Decile D10 (5.07 kg/person) and decile D1 (2.11 kg/person), explained by the size of household income.

The lack of financial resources has caused a large proportion of households not to be able to pay in time for the consumption of utilities. Thus, $36.0 \%$ of the total of these households, $29.1 \%$ of urban and $37.8 \%$ of the countryside did not have the possibility of timely payment of services related to housing maintenance.

The share of unemployed households who were unable to cope with the net income expenditures achieved in 2015 was $69.3 \%$, of which $35.3 \%$ could not pay on time the services related to housing maintenance, this figure rising to $38.5 \%$ in the urban environment. The electricity consumption bill could not be paid by $16.7 \%$ of the households, with $14.0 \%$ in urban areas and $19.4 \%$ in rural areas, the radio and television subscription could not be paid on time by $6.6 \%$ of the households, and the invoice by $6.4 \%$.

The share of households that have turned to savings to cope with current expenditures was $6.8 \%$, those whom made loans from relatives, friends or other persons $6.1 \%$, and those who needed financial aid without the obligation to restitution, from relatives, friends or other persons was $11.5 \%$. Additional work for obtaining the resources needed to cope with current expenditure was carried out by $9.3 \%$ of households. 


\section{Conclusions}

The development of society is closely linked to the changes that it knows, over time, the society's economy: the structures in which it is carried out (forms of ownership, classes and social groups, types of households or businesses, etc.), the production, transport and communication it uses, the type of operating mechanism of the economy (decentralized, centralised), the rules for the distribution and movement of resources and the results of economic activity, relations between people, including relations between different categories of economic agents and political power (state), the ratio between the economic activity of people and the natural environment in which it is carried out, etc.

The level and structure of consumption differ sensibly from a socio-professional category to another. If voluntary simplicity were adopted on a wider scale by those whose basic needs were satisfied, it could put the foundations of a society that accepts fundamental socio-economic equality much easier than companies that register a ostentatial consumption. What separates the need to mere desire is the criterion of necessity that would characterize the need, whatever the degree of necessity and whatever the urgency of this need.

To eat, to drink, to have protect against cold constitutes undeniably physiological needs. Any organism have to feed in such a way as to survive. The amount of calories indispensable to survive depends on the climate, individual, level of activity. In addition, account should be taken of the calculation of food ration, protein needs, lipides, carbohydrates, vitamins, even physiological needs having a cultural and historical component.

Social policy refers to the way in which the state manages to respond to the varied needs of the individuals expressed throughout the life (Stănescu, 2013, p.31). Some are satisfied by market mechanisms, others by family or community.

\section{References}

Bădescu C. (2013). Fundamentele culturale ale crizelor economice de la etno-economie la teoria proprietății identitare, Bucuresti: Editura Muzeului Naţional al Literaturii Române

Cace S., (2004). Statul bunăstării. Evoluţii şi tendințte, Bucureşti: Editura Expert, p.39.

Doboş C. (2005). Serviciile publice de sănătate şi dezvoltarea socială, Revista Calitatea Vieții. (3-4), p.3

Iagăr E.M. et al. (2016) Coordonate ale nivelului de trai în România. Veniturile și consumul populatiei în anul 2015, Bucureşti

Păun I O. (1994). Agricultura României la cumpăna dintre mileniile II şi III, Timişoara: Editura Helicon, p.64

Stanciu M. (coord.) (2012). România în austeritate, Braşov: Editura OMNIA UNI S.A.S.T.

Stănescu M. S. (2013). Statul bunăstării intre supraviețuire, reformă și integrare europeană, București: Editura Pro Universitaria, p.31.

Vela A. (1981). Dinamica structurii economice în ţările în curs de dę̧voltare, Bucureşti: Editura stiințifică si enciclopedică, p.257

Zamfir C. (coord) (1994). Dimensiuni ale sărăciei, Bucureşti: Editura Expert, p.56. 
96 | The welfare of romanian society viewed from the historical and socio-economical perspective

*** (1964). Agricultura României 1944-1964, Bucureşti: Editura Agro-silvică, p.49

***1945). Comunicări științificice (2)

*** (1948). Comunicări știintsifice (19)

*** (1949). Economic Survey of Europe in 1948, Genève, p.235.

*** (1940). Recensământul populației, p.133.

*** Romanian Encyclopedia vol.III.

*** (1940). Romanian Encyclopedia, vol.III. Evoluția economiei românești, p.39, p.224.

*** (1940). Romanian Encyclopedia, vol. IV, p.223

INS (1991) Anuarul Statistic al României 1990, Consumul mediu anual pe locuitor la principalele produse alimentare şi nealimentare, Bucureşti, pg.129

INS (1991) Anuarul Statistic al României 1990, Structura cheltuielilor totale de consum ale familiilor de salariați şi de țărani cooperatori cercetate pe eşantionul bugetelor de familie pe grupe după mărimea familiei, Bucureşti, pg.129

INS (2017) Anuarul Statistic al României 2016, Tab 4.23, p. 225

http://www.rasfoiesc.com/educatie/istorie/STRUCTURI-SI-MISCARI-SOCIALE-I92.php. Accessed on 05.10.2017

http://www.digi24.ro/stiri/actualitate/social/555-bucurestiul-meu-bucuresti-orasul-in-care-s-apracticat-comertul-cu-afurisenii-309300. Accessed on 05.10.2017

http://adevarul.ro/locale/targu-jiu/sanatatea-extrem-proasta-romanilor-perioada-interbelica-treimilioane-copii-morti-intr-o-perioada-22-ani-1_57d96d095ab6550cb8a8acbe/index.html. Accessed on 09.10.2017 